\title{
Analysis of the Crime of Unlawful Seizure of State and Public Property
}

\author{
Kamran Kouhbaei ${ }^{1}$ \\ ${ }^{1}$ Islamic Azad University, Persian Gulf International Branch, Iran \\ Correspondence: Kamran Kouhbaei, Islamic Azad University, Persian Gulf International Branch, Iran. E-mail: \\ Kamran.kouhbaei2012@gmail.com
}

Received: July 9, 2016 Accepted: October 19, 2016 Online Published: November 30, 2016

doi:10.5539/jpl.v9n10p113 URL: http://dx.doi.org/10.5539/jpl.v9n10p113

\begin{abstract}
Unlawful seizure has the importance and a particular priority (from the criminal dimension) as one of the abuses of government officers than state and public funds and property in the legislative system. This importance is so strong that crimes in the unlawful seizure warrants in non-criminal laws in the years after the revolution. Unlawful seizure is including crimes against state property (in the general sense) that can be studied among criminal law from the crimes issues against property and ownership. Since the perpetrators of the crime are from the employees of governmental and public agencies Due to the lack of expertise, increasing the charge of the government and large volumes of laws and regulations are not aware of the three elements of the crime. Abundant contact of staff with the attracted target and their extension, that in the meantime, control all aspects of those objectives is facing constraints caused by government departments with the highest number of regulatory bodies in the field of witness. Also weakness of moral values and fading of the obscenity of crimes is caused reputational reduce costs and increase the number of perpetrators of crime detection, and is resulted the inability of management and supervisory institutions in the control of crime. In the prevention of this crime, relying on secondary prevention in people at risk of criminal policy can be effective, and training the various concepts and concepts that are effective in reducing crime. In any form, strengthening of regulatory bodies and religious and ethical values, transparency of rules as the best way of preventing or reducing crime in the area has been proposed. In this study, the author tries to explain the crime of illegal possession of public funds in accordance with the Code of Criminal Procedure the country. It should be noted that this type of research in the article will be libraries and analytical method, data and information.
\end{abstract}

Keywords: unlawful seizure, Government employees, state and public property

\section{First Topic: The Concepts and Definitions of the Crime of Unlawful Seizure}

\subsection{The Definition of Unlawful}

The term "illegal" is as a negative adjective, in other words, negate structure is indicated change correct situation of a legal action to the criminal and improper state. So that accurate seizure and domination that it is protected through compliance with the law by adding the description of "illegal" as the mass effect and representative pursuant to prosecute and punish perpetrators would be more to come. The phrase of illegal in some works of great scholars of the "unauthorized" or "illegal" or "unlawful and forcible" is known synonymous, but it is obvious that mentioned description has been indicated on "unlawful seizure" versus "lawful seizure " that recent description is included "material and practical hands on something so that it holds the authority to make legislative intervention in the matter." Therefore, in case of violation of law or the legal order has been used, and if it is committed or the subject of a criminal law should be part of the discussions, it can be caused to prosecute its perpetrator or perpetrators.

\subsection{The Definition of Governmental Property, Public Property}

\subsubsection{The First Clause: State Property}

In relation to the definition of "state property", Article 2 of the bylaws of state property July 17, 1993Council of Ministers and amendments related to the number 10863 / D / 15081 dated 05.09.1374 is stated. "State property: property purchased by the ministries and public institutions, or to any legally owned by the state in the bus or come in." In this regard, the Legal Department, the Judiciary has defined the state-owned property. "State 
property is included whole country public budget, and are at the disposal of three branches of power, public companies and organizations and the Guardian Council."

It is worth noting, according to the state property regulations, property of state companies is also considered retail of state property, but with the approval of Act No. 10863/15081 of the Council of Ministers dated March 29,1995 have been the property of such companies, including foreign government property. With the approval of Act No. 10863 /T $15081 \mathrm{H}$ dated March 29, 1995of the Council of Ministers property is brought out such companies including of state property. Of course, in this regard, some definitions have been expressed by precious rights professors that are referred to 2 cases in the following:

- "Under Article III of the Regulations of state property to No. 4/349 dated december 30, 1995" any property, movable and immovable of state property that is in the possession of government property. "

- "state property refers to property that is according to government rules and regulations, and it is used to perform the duties or exercise of their sovereignty and enterprises".

As a result, it can be said that the relationship between the government and of state property as "property" is verifiable and substantiated, and as such it the government is the owner of such property and by law cannot make any changes in them.

\subsubsection{Second Clause: Public Property}

In a general sense we can say: "public property" is defined as "all the property which directly or indirectly, by the Government to resolve needs of dedicated public." In other words, what the government is to provide public service dedicated to public property. Because they are public property has its own characteristics so the laws on private property such as detention, transfer, etc. do not apply.

\section{The Second Issue: The Definition of the Crime of Unlawful Seizure of State and Public Property}

In previous discussions about the "unlawful seizure" and "state and public property" was presented matters, now on this topic to a subject was entitled "The unlawful seizure of state and public property", the purpose of this is that in fact the author has been discussed the nature and totality of crime(Ie, capture in government and public funds). Indeed this topic is completed previous discussions.

\subsection{First Article: In Law}

Take a look at the provisions of Article (598) of the IPC (the Ta'zirat) approved April 22, 1996, as well as other cases that in past and present to the mentioned crime or the subjects addressed in order, is confirm of failure to definition of mentioned crime by the legislator. Indeed, legislator is performed just to mention its various manifestations instead of defining described crime, and thereby has been provided result in providing different views on this matter. So in order to achieve comprehensive and exclusive definition must be considered the definition offered by our lawyers in this regard.

\subsection{Second Article: In the View of Lawyers}

In order to resolve the gap, the lack of definition of unlawful seizure of state and public funds and property in the laws, some teachers have said the worthy definition that below are mentioned some of them:"Unlawful seizure is included embed unauthorized use of funds or securities or approved credits or documents or property belonging to the state or the treasury by an employee of the government agencies or other authorities mentioned in Article (598) of punishment."

"Unlawful seizure is included spending state funds and movable property the treasury without legal authorization."

"Seizure without legal authority of trustees of state property (Or assets that belong to those individuals and the government holds in trust for them) in movable property that are faithful in their maintenance." "Spending a local public revenues which he has not been the site of component private credit, and spending local revenues which basically spending on the component public funds have been approved, but delays in the processing its applications and awaiting permission are not caused death, and spending private local revenues which basically spending at the site have been approved component of private credit and delays in processing, and expect is not caused of issuing permits of dead. Finally processing of applications that its validity is not approved, and administrative expediency is not required its use."

"Unlawful seizure is included use and unauthorized use of public funds and public property and public employees and officers responsible for negligence and wastage or maintenance of the property and funds". 


\section{Third Topic: Criminalization of Unlawful Seizures in Islamic Criminal Law and Rights in Iran}

Unlawful seizure in the state and public property is indecent, reprehensible behavior and contrary to the sacred religion of Islam, but for explaining consequences, and thus it can not only rely on the words to seize Unlawful in the Islamic criminal law have and in the criminal law of retribution and punishment has been predicted.

\subsection{References of Unlawful Seizure of Crime in State and Public Property}

\subsubsection{The First Clause: Legal Sources}

A: In criminal law

Historically in Iran's Penal Code on charges of illegal possession of public funds and property, it is worth noting the General Penal Code (1925) is the first law that in their discussion entitled "in abuses by government agents relation to the state" under Article (152) has been known as follows:

"Each collector and their assistants and trustees and auditors and trustees of public funds that the cash reserve is belonging to the State or persons or documents or demands that is as a cash reserve or securities or money transfers or documents or tangible objects that is according to the role deposits to them, embezzlement or any unlawful seizure in addition rejection of property and compensation of blood money of the weakness of property compensation will be condemned".

In the following, in 1928, the legislator on the basis of clause (8) Article (26) of the Penal Code Amendment to Penal Code of the scope of the duty of the government's actions due to legislation or administrative systems has been developed foregoing subject matter has decreed:

"The purpose of the duty referred to in Article 152 Penal Code task that is not only determined by law or administrative regulations, but any formal or informal work and the duty of the employee or the supervisor actually is performed, his role should be recognized, and the unlawful seizure of property referred to in Article 152 that is by law or administrative regulations or history of or above the deposit to the employee or his subordinate employees that have been considered by virtue of the abovementioned embezzlement, even though before this interpretation has been committed a crime, and even if the incapacity or prohibition was issued against it in Criminal Court trial and was sentenced to punishment grafter unless the amount embezzled fifty thousand dollars or less, in which case the Administrative Court will stand trial. "

Also in the Article a penal code for perpetrators of the crime of unlawful seizure of January 6, 1928 approved by grafters of state property and dismissal from public service in addition to a fine, imprisonment is imposed instead of a fine.

On the other hand, Article (400) of the trial and punishment of the Army Act 1929 has been stated:

"Each manager or accountant and cashier or teller system of cash reserve is belonging to the State or persons or documents and material that is as a cash reserve or securities or money transfers or documents or tangible objects that is according to the role deposits to them, embezzlement or any unlawful seizure in accordance with the provisions of Articles 53 and 54 of this law in addition to the rejection of the same or solitary confinement from two years to ten years for it is sentenced, and if the means or objects in terms of the amount or value of does not exceed five thousand riyals committed crime is ordinary imprisonment from six months to three years in addition to rejecting of property. If the crimes mentioned in this article at the time of campaign is committed or military operations, committed to working imprisonment of three to fifteen years will be condemned, but when the crime results in irreversible damage to the army's operation or commit cash reserve or documents against the interests of the state to spend the money transfers had been sentenced to death. "

Let's look at the rules under which crimes related to illegal land occupation and embezzlement in 1318 in a legal matter has been brought, and for both of them by virtue of this thinking creates a single virtual view that the legislator has equated the two objects, and so for both, the same penalty has been assumed, but the author believe it is important to confirm these laws a careful examination that has been known, and on this basis it has determined punishment. In the following, in the 1973 legislative reforms, believing in the existence of differences between the two embezzlement and unlawful seizure, these two issues are separate and special law for each Article is considered. In this regard in Article (152) of embezzling and in Article (153) to capture the illegal payment as follows:

Any of the mentioned persons in the above article that is stated in the funds and property that is used unauthorized according to the role that they have. Without the intention of taking possession of it to their advantage or else is considered squatters will be punished as follows. 
1) If the funds and property to their advantage or else make unauthorized use, and is the amount of benefit from ten thousand and a hundred thousand Rials, it is committed to six months to three years in prison for misdemeanors and if the amount is over, is sentenced to two to ten years in prison for second-degree criminal and permanent dismissal from service, and in both cases rejected in addition to a fine equal to twice the amount of profit it will be condemned.

2) With respect to the funds and property have been deliberately consumed that basically has not been considered in the credit law for it or in other specific cases or in excess of approved credits, and it is more than ten thousand committed ato the misdemeanor in prison of six months to three years will be convicted. The same prescribed punishment for a man who people trust funds contrary to the legal provisions in the organization or institution has been consumed.

3 ) If the property referred to in paragraph one or two funds and is not more than ten thousands, and in other cases where funds or property without taking action legislation is committed a administrative violations and the administrative court prosecution will be. Deposit Capture or non-receipt of any wrongdoing in the cases have been predicted by law or contract or pay a deposit before the deadline that has been set that is covered by this clause.

Amendment 1: Committed to an institution as mentioned in this material are unlawful seizure warrant, and the perpetrator in each case, to the penalties prescribed in the above article unless the act is required severe punishment.

Amendment 2: Whenever it is confirmed the perpetrator is consumed in terms of administrative requirements with social interests and property funds otherwise specified or in excess of approved credits, or has been made the unauthorized commitment that is suggested by the Minister of Justice or Ministry to be excused from the proceedings of the Committee of Ministers. However if the perpetrator has been violated to other financial regulations, will be traceable in the Administrative Court.

Amendment 3:In all cases that unlawful seizure has been caused losses, victim of the crime as the case from law Court has been required its losses. In about subparagraph of this article when the amount of losses is exceed the amount of the benefit, the court will be the difference. "

Mentioned belief of the existence difference between desired crimes are also prevailed at the time of adoption of the Ta'zirat law in 1983, and Article (76) of the law in the section "abuses by government agents relation to the state" guilty of unlawful seizure has been allocated as follows:

"Each of the persons mentioned in the previous article contained in the material or financial funds and property that holds according to the role, unauthorized use without having the intention of taking possession of it or else have been to their advantage, illegal occupants in addition to compensation and salary as saying sentenced up to 74 lashes, and also if wastage has caused due to negligence or violation of government property and funds, and uses it to bring that is not included in the authorizing statute for it, or it is used in the other specific cases in excess of credit is consumed".

The legislative process in the dealing with the perpetrators of the crime of unlawful seizure continued until the date May 23, 1978legislator in Article (598) of the IPC (the sanctions) under Chapter XIII entitled "An incursion by government officials relation to the state" has lyrics:

"Each employee and administrative staff and organizations or councils and municipalities and agencies, or affiliated with the government or revolutionary organizations and foundations and institutions that are run under the supervision of the Supreme Leader and the Court of Audit and institutions are run continuous help of the government, and or of judicial base andin general, staff members and three branches as well as the armed forces and public services, both formal and informal agents, funds or stocks or materials or money transfers and other documents, securities or other property belonging to any of the above-mentioned organizations and institutions or persons according to the role have been entrusted to them are unauthorized use without having the intention to their advantage of the other possession, seizure is considered unlawful, and in addition to indemnification of damages caused and salary is sentenced to up to 74 lashes, And also in case due to negligence and extremism is caused loss of property and state funds and uses it to bring that is not considered in credit law for it or in cases in excess of consumer credit has made. "

So now Article 598 of the Penal Code (the sanctions) in dealing with the perpetrators of the described criminal offense has the ability and power to run.

1) Unlawful seizure of state and public funds and property; 
Clause (T) Amendment 1, annual budget law 2005 of the whole country, December 27, 1993, clause (T) of Article (23) of the Supreme Audit Court, adopted on January 31, 1983.

2) Unlawful seizure of state funds and property;

Amendment (3) of Article (70) Public Audit Act, Clause (3) of Article (70) Public Audit Act, Amendment (3) of Article (70) Public Audit Act, Clause (2) of the Law Concerning amendment (63) and (64) public Audit Act, Amendment (2) of the law Concerning amendment (63) and (64) public Audit Act, Article (93) public Audit Act, clause (e) Amendment (20) of the budget 1384 of the whole country.

3) Unlawful seizure in state property;

Article (69) and the following provisions of the law regulating the part of the government's financial regulations and amendments under that Act of February 16, 2002, Article 9 of the Regulations law to ban ministries and agencies, printing and publication of unnecessary, adopted on January 13, 2002. Amendment (5) of the Law Concerning Prohibition of ministries and agencies, printing and publication of unnecessary, adopted on October 20,1986, Clause (1) of spending public funds in accordance with the law and other regulations are excluded from compliance calculations September 30, 1979.

Article (5) government cars and selling cars the use of waste legislation, September 26, 1979 approved.

- Unlawful seizure in the public property; March 14, 1980. Parliament of specific joint Commission, the first part of clause 5 of General Budget Law 2005, Article (3) of the regulation to reduce unnecessary costs and avoid luxury, approved on January 17, 1992.

4) Unlawful seizure;

Article (104) Social Security Act, approved on May 25, 1975, July 19, 1975.

5) The unauthorized seizure of public property;

Clause (J) of Article 18 of the Fourth Economic, Social and Cultural Islamic Republic of Iran.

6) In order unlawful seizure of funds and state property;

The last part of clause (T) Amendment (1) 2003 General Budget Law, Article (93) Public Audit Act, paragraph, Amendment (6) of the country's 1993 budget, Clause (d) of Note (3) of the Amendment the country's Amendment budget, Amendment (47) 1993 General Appropriations Act, clause (8) of the country's 1373 budget, clause (b) Amendment (6) of the 1373 national budget, Amendment (53) annual budget law in 1993 the whole country.

7) In sentence of unlawful seizure in the state property;

Amendment (13) 1994 General Appropriations Act, Clause (Z) of Amendment (22) of the 1993 general budget, section (f) of section 2 Clause (g) of clause (1) of the 1995 national budget, Amendment (2) Article 9 of the implementing regulations row 1 (a) Amendment (46) of the 1996 national budget.

8) In the sentence of unlawful seizure of public and state property;

Article (32) of Drafting Part of State Financial Regulations, adopted on october 29, 2001.

9) In the sentence of unlawful seizure of state and public funds;

Clause (B) Amendment (5) budget Law for 2004 of the whole country.

\section{Conclusion}

The conclusion was emphasized the importance of misdemeanor unlawful seizure in state and public funds and property in all phases of the legislative system of legislative. Although some of the laws related to the issue from the transparency is not satisfactory, but the importance of the debate has been crucial. On the other hand, expand the scope of its material basis in the laws and regulations enacted by legislators and are mainly financial and accounting is a subject that emphasized the importance of legislative system that has a close relation with establish of financial and economic order.Of course, even though apparently only the victim is the actions of state and public agencies, but in the alternative to the other persons, victims are also affected. For example, in the case of credit for the project in the budget law is stipulated by legislators or authorities. And its contractors by relying on this account after participating in the tender process, with executive contracts, but the order of the highest authority of the executive or financed by the comptroller that is auditor much of the credit goes wrong side of such machines. The contractor is performed agreed operation with contract requirements that have been spent regardless of part of the validity of certain projects in other cases, and the contractor has not been achieved despite their commitment to mutual commitment. This system of economic inflation is caused losses to him. 
In the expression of the crime of unlawful seizures can be said: This crime is one of the specific crimes of employees and government employees. Therefore, in the inclusion of crimes against state property has been classified. From the perspective of penology, with the attitude in the history of criminal law of this crime can be claimed by reducing the amount and severity of the punishment, from misdemeanor imprisonment (5 to 10 years) has been sentenced to be whipped up to 74 strokes of the factors that has been more prevalent. On the other hand, despite the ongoing emphasis on agility of legal requirements, Fitting and rationalize the organization of government and policies reduction of its overall policy administrative system, Fourth and Fifth Development Program Rules and General Policies of Article 44 of the constitution, the government is responsible for many cases of Policies that the same applies is caused widen of the field for such crimes. However, in terms of stewards misdemeanor, with a real attitude of the government, with the change at the head of the Executive Branch, change management has become a common trend, and are faced with the power of each state collection the maximum life span of 8 years and the arrival of new executives laws and regulations that are with the concepts of most of them. In hiring and promotion rules and the appointment of managers and government employees in addition to taking into account the principle of merit, enhanced and knowledge is considered special importance fore and management skills.

So now the expression of the crime of illegal seizure of public property can be said that this crime has been special of employees and government employees regardless of the type of employment relationship, including formal, informal, etc that in terms of fulfilling legal obligations is captured government and public property and funds, and without the intention of the government's expropriation of funds and property, unauthorized attempts to capture them. It is worth noting that existence of intent is not required for realization of this crime, and seizure or unauthorized use in desired funds and property are provided its realization. Furthermore illegal seizing, benefiting is not necessary.

\section{References}

Amid, H. (1995). Amid dictionary (4th ed.). Tehran, Amir Kabir Publications.

Amini, S. K., \& Goudarzi, F. D. (1999). the administration of property (1st ed.). Tehran, Nour publications.

Asayesh, A. (2007). dedicated criminal law (Vol. II, 3rd ed.). Tehran, Mizan publications.

Bagher, A. (2002). Majd Law Dictionary (English-Farsi) (3rd ed.). Tehran, Majd Publications.

Dastghaib, A. H. (1984). cardinal sin (1st ed.). Qom, Islamic publications.

Dehkhoda, A. A. (1994). Dehkhoda Dictionary (Vol. II, 2nd ed.). Tehran, Dehkhoda Institute.

Fanaee, S. A. (1999). against the applied Arab-Persian words (1st ed.). Mohsen.

Imami, S. H. (2000). Civil Rights (Vol. I). printing twenty-first, Qom, Islamia publications.

Katouzian, N. (1999). property and ownership (Civil Rights Foundation course) (2nd ed.). Tehran, publishing of Justice.

Langroodi, J., \& Jaafar, M. (2001). property rights (5th ed.). Tehran, Ganj Danesh publishications.

Moeen, M. (1983). Persian dictionary (Vol. I). Tehran, Amir Kabir Publishing Institute.

Moslehi, M. (2001). Law Dictionary (English-Farsi). Tehran, Afarinesh publications.

Sadri Afshar, G. H. (1994). Persian culture today (1st ed.). Tehran, Word Institute.

Shjay, F. (2008). the crime of illegal seizure of public funds and public property in Iran Criminal Law, Master's thesis, Tarbiat Modarres University in Tehran.

Tabatabaee Motameni, M. (2007). Administrative Law (2nd ed.). Tehran, Samt publishications.

Validi, M. S. (2002). dedicated criminal law (crimes against property or property) (Vol. I, VII). Institute of Amir Kabir University Press.

Zaefaranchi, M., \& Amouzegar, H. (1991). Persian dictionary to knowledge Persian (1st ed.). Tehran, Safar publications.

\section{Copyrights}

Copyright for this article is retained by the author(s), with first publication rights granted to the journal.

This is an open-access article distributed under the terms and conditions of the Creative Commons Attribution license (http://creativecommons.org/licenses/by/4.0/). 